CRY1 and CRY2 genetic variants in seasonality : A longitudinal and cross-sectional study

Kovanen, Leena

2016-08-30

Kovanen , L , Donner , K, Kaunisto , M \& Partonen , T 2016 , ' CRY1 and CRY2 genetic variants in seasonality : A longitudinal and cross-sectional study ', Psychiatry Research, vol. 242 , pp. 101-110 . https://doi.org/10.1016/j.psychres.2016.05.044

http://hdl.handle.net/10138/225830

https://doi.org/10.1016/j.psychres.2016.05.044

publishedVersion

Downloaded from Helda, University of Helsinki institutional repository.

This is an electronic reprint of the original article.

This reprint may differ from the original in pagination and typographic detail.

Please cite the original version. 


\title{
CRY1 and CRY2 genetic variants in seasonality: A longitudinal and cross-sectional study
}

\author{
Leena Kovanen $^{\mathrm{a}, *}$, Kati Donner ${ }^{\mathrm{b}}$, Mari Kaunisto ${ }^{\mathrm{b}, \mathrm{c}}$, Timo Partonen ${ }^{\mathrm{a}}$ \\ a Department of Health, National Institute for Health and Welfare (THL), Helsinki, Finland \\ ${ }^{\mathrm{b}}$ Institute for Molecular Medicine Finland (FIMM), University of Helsinki, Helsinki, Finland \\ c Folkhälsan Institute of Genetics, Folkhälsan Research Center, Helsinki, Finland
}

\section{A R T I C L E I N F O}

\section{Article history:}

Received 3 February 2016

Received in revised form

27 May 2016

Accepted 30 May 2016

Available online 30 May 2016

Keywords:

Behavior

Circadian

Cryptochrome

Diurnal

Genetic association

Mood

Population

\begin{abstract}
A B S T R A C T
Cryptochromes are key components of the circadian clocks that generate and maintain seasonal variations. The aim of our study was to analyze the associations of CRY1 and CRY2 genetic variants with the problematicity of seasonal variations, and whether the problematicity of seasonal variations changed during the follow-up of 11 years. Altogether 21 CRY1 and 16 CRY2 single-nucleotide polymorphisms (SNPs) were genotyped and analyzed in 5910 individuals from a Finnish nationwide population-based sample who had filled in the self-report on the seasonal variations in mood and behavior in the year 2000. In the year 2011, 3356 of these individuals filled in the same self-report on the seasonal variations in mood and behavior. Regression models were used to test whether any of the SNPs associated with the problematicity of seasonal variations or with a change in the problematicity from 2000 to 2011. In the longitudinal analysis, CRY2 SNP rs61884508 was protective from worsening of problematicity of seasonal variations. In the cross-sectional analysis, CRY2 SNP rs72902437 showed evidence of association with problematicity of seasonal variations, as did SNP rs1554338 (in the MAPK8IP1 and downstream of CRY2).
\end{abstract} (c) 2016 Elsevier Ireland Ltd. All rights reserved.

\section{Introduction}

For the majority of the human population, there are fluctuations in mood and behavior across seasons (Kasper et al., 1989). Among individuals having mood disorder these seasonal variations tend to be pronounced (Wehr and Rosenthal, 1989). Seasonal variations characterize the clinical picture of those with the seasonal pattern or seasonal affective disorder (SAD) (Rosenthal et al., 1984b). The winter type of SAD is the most common form (Partonen and Lonnqvist, 1998; Patten et al., 2016). Earlier, we have shown that, of the Finnish general population aged 30 and over, $85 \%$ which corresponds to the estimated number of $2,766,037$ inhabitants followed a seasonal pattern in mood and behaviors, $38.9 \%(1,266,531$ inhabitants) experienced routine seasonal variations to the extent of threshold-level SAD, and 2.6\% (85,615 inhabitants) suffered from these symptoms to the extent equal to SAD (Grimaldi et al., 2009).

Physiological functions and behaviors demonstrate daily and seasonal variations that are generated and maintained by the circadian clocks responding to stimuli from the habitat (Meijer et al., 2007). Within cells on molecular level, cryptochromes guide a

\footnotetext{
* Corresponding author.

E-mail address: leena.kovanen@thl.fi (L. Kovanen).
}

range of functions of the circadian clocks (Lamia et al., 2011), and they are necessary for the development of intercellular networks in the master circadian clock in the cells of the suprachiasmatic nucleus (Ono et al., 2013) that produces synchronizing signals throughout the organism (Evans et al., 2015). Environmental light and ambient temperature of the external 24-hour cycle act together to dictate the phase and to entrain circadian clocks (Boothroyd et al., 2007), but the change of seasons tends to challenge their functions (Stoleru et al., 2007). Since most biochemical reactions respond robustly to temperature, it might have been used as the original, universal time-giver to the organism (Buhr et al., 2010), and the evolution of mechanisms to buffer the effects of day-to-day (or season-to-season) changes in ambient temperature expected to favor adaptation (Francois et al., 2012). Concerning day-active animals, transcription of the cryptochrome genes that are key components of the circadian clocks is induced in the evening (Lincoln et al., 2002), and the heat-induced phase shifts of the circadian clock are severely reduced in the cryptochrome lossof-function mutants (Kaushik et al., 2007). Thus, the cryptochrome proteins regulate the temperature entrainability, and if this were to hold for mammals as well, including humans, then dysfunction of cryptochrome proteins may contribute to the seasonal variations in mood and behavior being experienced as a problem.

Dysfunction of the circadian clocks has been hypothesized to play a role in the etiology of mood disorders (Bunney and Potkin, 


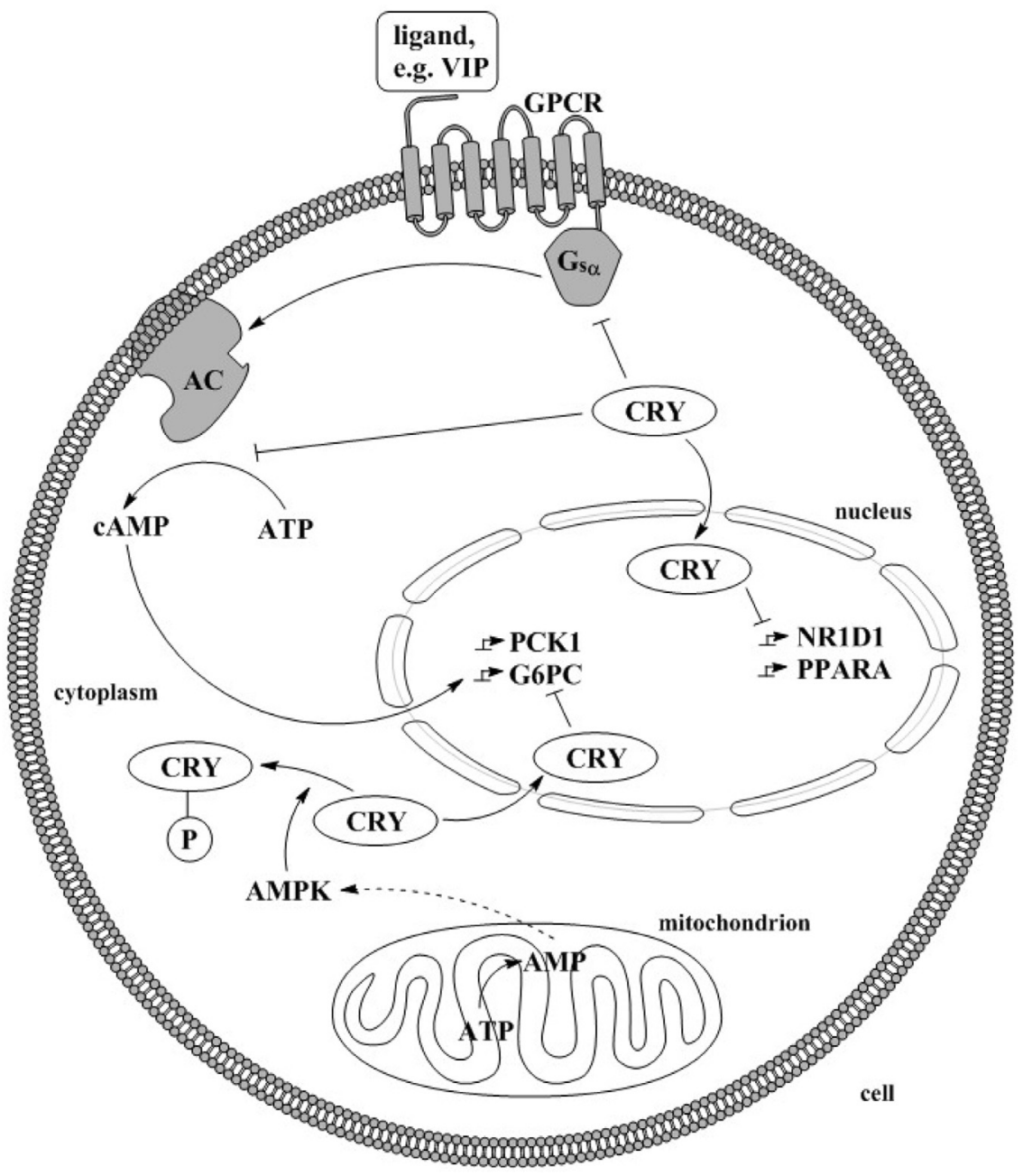

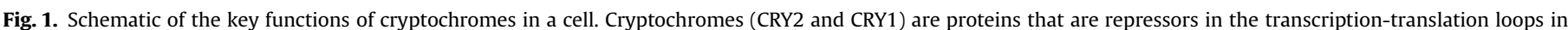

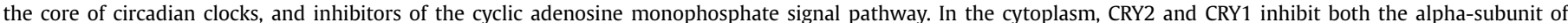

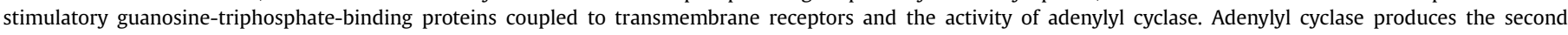

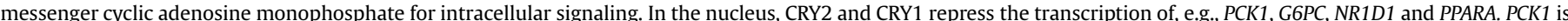

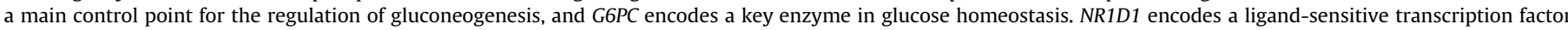

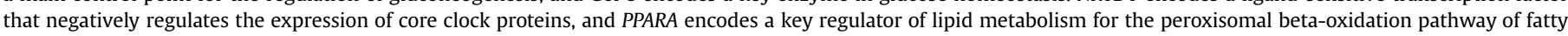

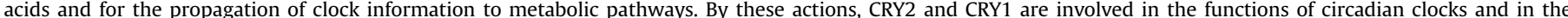

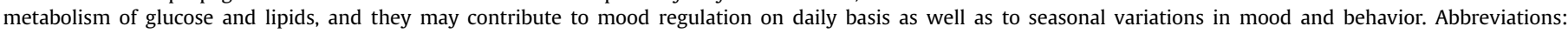

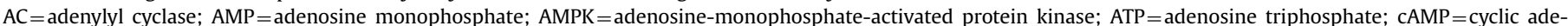

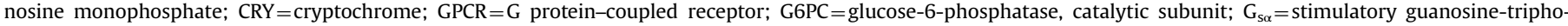

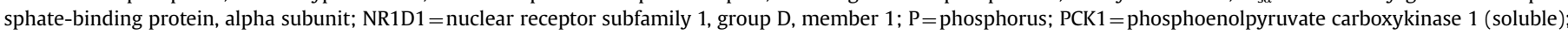
PPARA $=$ peroxisome proliferator-activated receptor alpha; $\mathrm{VIP}=$ vasointestinal peptide

2008). Those genes which encode repressors of transcription are thought to be of key importance, since they are essential to the normal function of circadian clocks (Ukai-Tadenuma et al., 2011). Here, the cryptochrome circadian clock 2 (CRY2) and cryptochrome circadian clock 1 (CRY1) proteins are the key repressors in the core of the circadian clock (Dardente et al., 2007; Ozturk et al., 2007; Ye et al., 2011, 2014). However, CRY2 has a key role in balancing the expression of cryptochromes, as it not only acts as a general repressor, but also opposes in specific the actions of CRY1 and inhibits CRY1 from accessing to its targets too early (Anand et al., 2013). See Fig. 1 for a schematic of the key functions of cryptochromes in a cell.

CRY2 has been associated with depressive disorders (Lavebratt et al., 2010; Kovanen et al., 2013), bipolar disorders (Sjoholm et al., 2010), and greater chronicity of depressive symptoms in patients with major depressive or bipolar disorder (Fiedorowicz et al., 2012). On the other hand, CRY1 has earlier been associated with depression (Soria et al., 2010; Hua et al., 2014) and nominally significant association has been observed with lithium treatment response for bipolar disorder (McCarthy et al., 2011). However, no association with bipolar disorder has been observed (Shi et al., 2008; Nievergelt et al., 2005). Thus, data from the very beginning to date are so far consistent with the hypothesis that CRY2 and CRY1 proteins modulate circadian and emotional responses, and therefore CRY2 and CRY1 are highly interesting and relevant target to study the seasonal variations in mood and behavior in humans. Here, we hypothesize that there is a variant of CRY2 or CRY1 which increases the odds for seasonal variations in mood and behavior being experienced as a problem.

Cryptochromes may be involved not only in regulation of mood and behavior, but also in that of metabolism of glucose, cholesterol and triglycerides. In a consortium meta-analysis of genome-wide association studies using the Homeostasis Model Assessment indices of insulin resistance and beta-cell function, the A-allele of CRY2 SNP rs11605924 was found to associate with fasting glucose and beta-cell function, but not to play a major role in type 
2 diabetes (Dupuis et al., 2010). Later, only a nominal association of type 2 diabetes was seen with the C-allele of CRY2 SNP rs2292912, but the finding complemented earlier findings and pointed at the role for CRY2 in susceptibility to type 2 diabetes (Kelly et al., 2012). Recently, however, these findings were extended by showing that $C R Y 2$ SNP rs11605924 was associated with glucose levels in healthy children, adolescents and adults, the A-allele being identified as a glucose-raising allele (Barker et al., 2011). In addition, the minor alleles of the CRY2 SNPs rs11605924, rs10838524 and rs7933420 all revealed increases in fasting glucose in a sample of non-diabetic individuals with the family history of type 2 diabetes (Machicao et al., 2016). Furthermore, the A-allele of CRY2 SNP rs11605924 was confirmed to associate with fasting glucose, and shown to associate with the 2-hour glucose levels after the 75gram oral glucose tolerance test if administered during the winter, but not if administered in the summer (Renstrom et al., 2015). On the other hand, the minor C-allele of CRY1 SNP rs2287161 was shown to interact with the level of carbohydrate intake, that is both a susceptibility factor to type 2 diabetes and a characteristic of seasonal affective disorder, to modulate fasting insulin and insulin resistance (Dashti et al., 2014). To our knowledge, there are no earlier data on the associations of CRY1 or CRY2 variants with cholesterol levels or those of triglycerides. Here, we hypothesize that there is a variant of CRY2 or CRY1 which increases the odds for adverse profiles of glucose, cholesterol or triglycerides metabolism, and that such variant is more frequent among those with problematic seasonal variations in mood and behavior.

Our aim in this prospective study representative of the general adult population aged 30 years and older was to analyze, whether there is any CRY1 or CRY2 genetic variant, which associates with a change in the problematicity of the seasonal variations during the study period of 11 years, and therefore provides information on the prognosis. Here, we report CRY2 genetic associations with the problematicity of seasonal variations in mood and behavior, and in a longitudinal analysis, with worsening of the problematicity.

\section{Methods}

\subsection{Subjects}

Our sample included 5910 individuals who had given blood samples, taken part to the Munich-Composite International Diagnostic Interview (M-CIDI) (Wittchen et al., 1998) and filled in the self-report on the seasonal variations in mood and behavior during the winter months of the year 2000. Of these 5910 individuals

Table 1

Successfully genotyped $C R Y 1$ and CRY2 SNPs, their allele and genotype frequencies, and Hardy-Weinberg equilibrium $p$-values.

\begin{tabular}{|c|c|c|c|c|c|c|c|c|c|}
\hline Gene & SNP & BP NCBI36/hg18 & A1 & A2 & MAF & $\mathrm{A} 1 \mathrm{~A} 1$ & $\mathrm{~A} 1 \mathrm{~A} 2$ & $\mathrm{~A} 2 \mathrm{~A} 2$ & HWE $p$ \\
\hline \multirow[t]{20}{*}{ CRY2 } & rs7121611 & $45,864,142$ & $A$ & $T$ & 0.46 & $1218(21.0)$ & $2883(49.6)$ & $1711(29.4)$ & 0.96 \\
\hline & rs7121775 & $45,864,323$ & C & $T$ & 0.27 & $384(6.6)$ & $2326(40.0)$ & $3100(53.4)$ & 0.06 \\
\hline & rs61884508 & $45,864,932$ & $G$ & $T$ & 0.02 & $1(0)$ & $241(4.1)$ & $5600(95.9)$ & 0.52 \\
\hline & rs75065406 & $45,864,942$ & $T$ & $C$ & 0.04 & $13(0.2)$ & $421(7.2)$ & $5414(92.6)$ & 0.11 \\
\hline & rs3747548 & $45,869,013$ & $A$ & $C$ & 0.00 & 0 & $1(0)$ & $5847(100)$ & 1.00 \\
\hline & rs10838524 & $45,870,177$ & $G$ & $A$ & 0.48 & $1337(23.0)$ & $2897(49.8)$ & $1579(27.2)$ & 0.92 \\
\hline & rs2292913 & $45,877,529$ & $T$ & C & 0.05 & $18(0.3)$ & $590(10.1)$ & $5233(89.6)$ & 0.70 \\
\hline & rs7945565 & $45,878,992$ & $G$ & $A$ & 0.46 & $1213(20.9)$ & $2890(49.8)$ & $1695(29.2)$ & 0.79 \\
\hline & rs1401419 & $45,879,739$ & G & $A$ & 0.46 & 1211 (20.9) & $2909(50.1)$ & $1681(29.0)$ & 0.48 \\
\hline & rs72902437 & $45,882,258$ & C & $T$ & 0.03 & $2(0)$ & $313(5.4)$ & 5499 (94.6) & 0.45 \\
\hline & rs35488012 & $45,889,228$ & G & & 0.00 & 0 & 0 & $5854(100)$ & 1.00 \\
\hline & rs117531403 & $45,891,332$ & C & & 0.00 & 0 & 0 & $5848(100)$ & 1.00 \\
\hline & rs7123390 & $45,891,418$ & $A$ & $G$ & 0.29 & $431(7.4)$ & $2445(42.2)$ & $2915(50.3)$ & 0.01 \\
\hline & rs4755345 & $45,891,508$ & $A$ & $G$ & 0.05 & $18(0.3)$ & $598(10.2)$ & $5229(89.5)$ & 0.80 \\
\hline & rs76545099 & $45,891,667$ & $T$ & & 0.00 & 0 & 0 & $5850(100)$ & 1.00 \\
\hline & rs17787136 & $45,894,636$ & G & $C$ & 0.28 & $409(7.0)$ & $2385(41.1)$ & 3014 (51.9) & 0.03 \\
\hline & rs10838527 & $45,903,194$ & G & $A$ & 0.12 & 89 (1.5) & $1236(21.2)$ & 4509 (77.3) & 0.67 \\
\hline & rs2292910 & $45,903,613$ & $A$ & C & 0.34 & $650(11.2)$ & 2707 (46.6) & $2455(42.2)$ & 0.02 \\
\hline & rs3824872 & $45,905,605$ & $T$ & G & 0.25 & $372(6.4)$ & $2173(37.3)$ & $3276(56.3)$ & 0.65 \\
\hline & rs1554338 & $45,906,830$ & $G$ & $A$ & 0.05 & $14(0.2)$ & $528(9.1)$ & 5289 (90.7) & 0.77 \\
\hline \multirow[t]{22}{*}{ CRY1 } & rs4964513 & $107,375,758$ & $C$ & $T$ & 0.12 & $84(1.4)$ & $1224(21.1)$ & $4492(77.4)$ & 0.95 \\
\hline & rs714359 & $107,378,845$ & $A$ & G & 0.22 & $276(4.8)$ & $2006(34.6)$ & $3516(60.6)$ & 0.67 \\
\hline & rs12821586 & $107,380,452$ & $A$ & G & 0.11 & $72(1.2)$ & 1138 (19.5) & $4629(79.3)$ & 0.84 \\
\hline & rs2287161 & $107,381,140$ & C & G & 0.50 & $1408(24.3)$ & $2930(50.5)$ & $1461(25.2)$ & 0.43 \\
\hline & rs11113153 & $107,381,770$ & $T$ & C & 0.17 & $178(3.1)$ & $1624(28.3)$ & $3946(68.6)$ & 0.49 \\
\hline & rs8192441 & $107,385,454$ & C & $A$ & 0.01 & $1(0)$ & $136(2.3)$ & 5712 (97.7) & 0.56 \\
\hline & rs3741892 & $107,387,163$ & C & G & 0.49 & $1395(24.0)$ & $2937(50.6)$ & $1477(25.4)$ & 0.40 \\
\hline & rs10861688 & $107,394,048$ & $T$ & $C$ & 0.17 & $164(2.8)$ & $1642(28.2)$ & 4011 (69.0) & 0.82 \\
\hline & rs10861695 & $107,415,073$ & $A$ & $G$ & 0.49 & $1385(24.0)$ & 2901 (50.4) & 1474 (25.6) & 0.58 \\
\hline & rs10861697 & $107,419,662$ & C & G & 0.49 & $1352(23.3)$ & $2923(50.4)$ & $1521(26.2)$ & 0.48 \\
\hline & rs2078074 & $107,436,806$ & C & $T$ & 0.42 & $1017(17.7)$ & $2815(48.9)$ & $1930(33.5)$ & 0.87 \\
\hline & rs59790130 & $107,440,303$ & $T$ & C & 0.06 & $26(0.4)$ & $692(11.8)$ & 5131 (87.7) & 0.58 \\
\hline & rs10437895 & $107,440,824$ & C & $T$ & 0.49 & $1398(24.0)$ & $2936(50.5)$ & $1482(25.5)$ & 0.46 \\
\hline & rs10746077 & $107,441,552$ & $A$ & $G$ & 0.42 & $1027(17.6)$ & $2832(48.7)$ & 1960 (33.7) & 0.96 \\
\hline & rs11613557 & $107,442,315$ & $T$ & $C$ & 0.06 & $26(0.4)$ & $692(11.8)$ & $5130(87.7)$ & 0.58 \\
\hline & rs2888896 & $107,446,582$ & $T$ & C & 0.42 & 1019 (17.6) & $2830(48.8)$ & $1947(33.6)$ & 0.87 \\
\hline & rs11113179 & $107,452,785$ & $T$ & $C$ & 0.08 & $39(0.7)$ & $833(14.3)$ & $4942(85.0)$ & 0.53 \\
\hline & rs10746083 & $107,454,152$ & $T$ & C & 0.49 & 1391 (23.9) & $2941(50.6)$ & $1481(25.5)$ & 0.37 \\
\hline & rs4964518 & $107,466,217$ & $T$ & C & 0.07 & $30(0.5)$ & 778 (13.3) & $5027(86.2)$ & 1.00 \\
\hline & rs7294758 & $107,467,829$ & $A$ & $T$ & 0.01 & 0 & $97(1.7)$ & $5758(98.3)$ & 1.00 \\
\hline & rs17289712 & $107,468,968$ & $G$ & $A$ & 0.05 & $6(0.1)$ & $524(9.0)$ & 5308 (90.9) & 0.07 \\
\hline & rs10778528 & $107,473,962$ & G & $T$ & 0.48 & $1358(23.3)$ & 2926 (50.3) & 1533 (26.4) & 0.62 \\
\hline
\end{tabular}

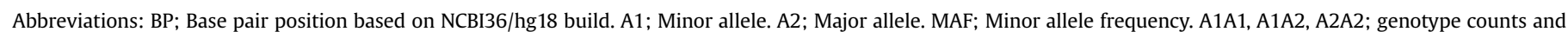
frequencies (\%). HWE; Hardy-Weinberg equilibrium. 
3356 filled in the self-report on the seasonal variations in mood and behavior again during the winter months of the year 2011. The sample is part of the national Health 2000 survey (Aromaa and Koskinen, 2004) of Finnish population aged 30 years and older $(n=8028)$ and its follow-up survey in the year 2011. The study was approved by the ethics committees of the National Public Health Institute and the Helsinki and Uusimaa Hospital District. The study was carried out in accordance with the principles of the Declaration of Helsinki and its amendments. All participants provided a written informed consent.

\subsection{Phenotypes}

The participants filled in a questionnaire of lifetime seasonal variations in mood and behavior adapted from the Seasonal Pattern Assessment Questionnaire (SPAQ) (Rosenthal et al., 1984a). The six items of sleep duration, social activity, mood, weight, appetite, and energy level had been scored from 0 to 3 (none, slight, moderate, or marked variation) rather than from 0 to 4 (none, slight, moderate, marked, or extremely marked variation). The psychometric properties of this modified questionnaire have been reported to be good (Rintamaki et al., 2008). The participants were also asked to what degree seasonal variations if any were a problem (no variations, no problem, and mild, moderate, marked, or severe problem).

For the purpose of the cross-sectional analysis, a variable was formed as follows: no seasonal variations (all six items no variation and problem degree no variations), non-problematic seasonal variations (at least 1 item with variation and variation is no problem), or problematic seasonal variations (at least 1 item with variation and variation is a problem). For the purpose of the longitudinal analysis, the individual change in the aforementioned variable was computed: equal $(n=1625)$, worse $(n=928)$, or better $(n=428)$. Supplementary material 1 shows the computation of the variables for the cross-sectional (Supplementary Table 1) and longitudinal analysis (Supplementary Table 2).

\subsection{Health examination}

Height and weight were measured, and the body-mass index (BMI) was calculated. Body circumference measurements were taken using a regular, flexible tailor's measuring tape at waist and hip level in line with recommendations for anthropometric measurements in population studies.

Current instructions of the Finnish Hypertension Society working group were followed for blood pressure measurements that were taken after calibration using a standard mercury manometer (Mercuro 300; Speidel \& Keller, Jungingen, Germany). The measurement was repeated two minutes after the first one, and the average of the two was used for analysis.

\subsection{Laboratory analyses}

As part of the health examination, venous blood samples were drawn and laboratory measures included in the analysis were total cholesterol (CHOD PAP, Olympus System Reagent, Freiburg, Germany), high-density lipoprotein (HDL) cholesterol (HDL-C Plus, Roche Diagnostics, Penzberg, Germany), triglycerides (GPO PAP, Olympus System Reagent, Freiburg, Germany), and plasma glucose (Hexokinase, Olympus System Reagent, Freiburg, Germany). LDL cholesterol was calculated with the Friedewald formula (Friedewald et al., 1972). All these samples were determined enzymatically with a clinical chemistry analyzer (Olympus AU400, Hamburg, Germany) at the Social Insurance Institution (Kela), Research and Development Unit, Finland. Plasma insulin concentrations were determined using a radioimmunoassay
(Phadeseph Insulin RIA, Pharmacia, Uppsala, Sweden). Homeostasis Model Assessment indices of insulin resistance (HOMA-IR) and beta-cell function (HOMA-B) were calculated according to the following formula: HOMA-IR $=$ fasting glucose $(\mathrm{mmol} / \mathrm{L}) \times$ fasting insulin $(\mathrm{mU} / \mathrm{L})$ divided by 22.5 and HOMA-B $=20 \times$ [(fasting insulin) divided by (fasting glucose minus 3.5)] (Matthews et al., 1985). Serum 25-hydroxyvitamin $D_{3}$ concentrations were determined using a radioimmunoassay (DiaSorin, Saluggia, Italy). The laboratory took part in the External Quality Assessment schemes (Labquality, Helsinki, Finland), the accuracy for the lipid determinations was also calculated by the Lipids and lipoproteins program, and the quality of the results of the series of all the analyses was ascertained.

\subsection{Gene and SNP selection}

CRY1 and CRY2 single-nucleotide polymorphism (SNP) selection was based on HapMap phase 3 data (http://www.hapmap.org/) and tagging was done using the Tagger program in the Haploview 4.1 software (Barrett et al., 2005). The linkage disequilibrium (LD), within the gene and $10 \mathrm{~kb}$ of their $5^{\prime}$ and $3^{\prime}$ flanking regions, i.e., $122 \mathrm{~kb}$ for CRY1 (chr12:105 899-106 $021 \mathrm{~kb}$, NCBI36/hg18 assembly), and $56 \mathrm{~kb}$ for CRY2 (chr11:45,815-45,871 kb), was used to select tag SNPs capturing most of the genetic variation. The aim was to capture all the SNPs having a minor allele frequency (MAF) of $>5 \%$ in the European population (CEU and TSI) in the HapMap database. The pair-wise $r^{2}$ was set to $\geq 0.9$ in order to select a tag SNP among the SNPs that were in LD. Ten out of 21 CRY1 and ten out of 34 CRY2 SNPs fulfilled the criterion and were all successfully included in the genotyping multiplex. In addition to the aforementioned tag-SNPs, 22 potentially functional variants in CRY1 (12 variants) and CRY2 (10 variants) were included in

Table 2

General characteristics of the participants $(n=5739)$ in the year 2000 .

\begin{tabular}{|c|c|c|c|}
\hline Characteristic & $n$ & $\%$ & \\
\hline \multicolumn{4}{|l|}{ Gender } \\
\hline Female & 3195 & 56 & \\
\hline Male & 2544 & 44 & \\
\hline \multicolumn{4}{|c|}{ Seasonal variation in sleep duration } \\
\hline Cases & 4178 & 73.88 & \\
\hline Controls & 1477 & 26.12 & \\
\hline \multicolumn{4}{|c|}{ Seasonal variation in social activity } \\
\hline Cases & 3980 & 71.72 & \\
\hline Controls & 1569 & 28.28 & \\
\hline \multicolumn{4}{|l|}{ Seasonal variation in mood } \\
\hline Cases & 4263 & 76.03 & \\
\hline Controls & 1344 & 23.97 & \\
\hline \multicolumn{4}{|l|}{ Seasonal variation in weight } \\
\hline Cases & 2771 & 49.47 & \\
\hline Controls & 2830 & 50.53 & \\
\hline \multicolumn{4}{|l|}{ Seasonal variation in appetite } \\
\hline Cases & 2404 & 42.68 & \\
\hline Controls & 3228 & 57.32 & \\
\hline \multicolumn{4}{|c|}{ Seasonal variation in energy level } \\
\hline Cases & 4235 & 75.34 & \\
\hline Controls & 1386 & 24.66 & \\
\hline \multicolumn{4}{|c|}{ Seasonal variation as a problem } \\
\hline No variation & 361 & 7.06 & \\
\hline Non-problematic variation & 3824 & 74.75 & \\
\hline \multirow[t]{2}{*}{ Problematic variation } & 931 & 18.20 & \\
\hline & $n$ & mean & s.d. \\
\hline Age, years & 5739 & 53.13 & 15.04 \\
\hline BMI, $\mathrm{kg} / \mathrm{m}^{2}$ & 5722 & 26.97 & 4.70 \\
\hline GSS, score points & 5469 & 5.04 & 3.07 \\
\hline
\end{tabular}

Abbreviations: BMI; body mass index. GSS; global seasonality score. 
Table 3

Baseline characteristics of the participants with problematic, non-problematic and no variation.

\begin{tabular}{|c|c|c|c|c|c|c|c|c|c|c|c|c|c|}
\hline & \multicolumn{3}{|c|}{ problematic variation } & \multicolumn{3}{|c|}{ non-problematic variation } & \multicolumn{2}{|c|}{ no variation } & \multirow[b]{2}{*}{$\% / S D$} & \multicolumn{2}{|c|}{$\begin{array}{l}\text { problematic vs. non- } \\
\text { problematic }\end{array}$} & \multicolumn{2}{|c|}{ problematic vs. no variation } \\
\hline & $\mathrm{n}$ & mean & $\% / S D$ & $\mathrm{n}$ & mean & $\% / S D$ & $\mathrm{n}$ & mean & & $\chi^{2} / \mathrm{t}$ & $\mathrm{p}$ & $\chi^{2} / \mathrm{t}$ & $\mathrm{p}$ \\
\hline Male gender & 365 & & 39.21 & 1675 & & 43.80 & 201 & & 55.68 & 6.27 & 0.01 & 28.01 & 0.0000001 \\
\hline Female gender & 566 & & 60.79 & 2149 & & 56.20 & 160 & & 44.32 & & & & \\
\hline Age & 931 & 53.55 & 15.07 & 3824 & 51.43 & 14.27 & 361 & 55.42 & 16.46 & -3.89 & 0.0001 & 1.87 & 0.06 \\
\hline Glucose & 931 & 5.58 & 1.38 & 3822 & 5.52 & 1.13 & 361 & 5.66 & 1.36 & -1.27 & 0.20 & 0.95 & 0.34 \\
\hline Total cholesterol & 931 & 5.93 & 1.16 & 3822 & 5.91 & 1.09 & 361 & 6.00 & 1.13 & -0.54 & 0.59 & 0.96 & 0.34 \\
\hline HDL cholesterol & 931 & 1.33 & 0.38 & 3822 & 1.34 & 0.38 & 361 & 1.29 & 0.37 & 1.11 & 0.27 & -1.69 & 0.09 \\
\hline LDL cholesterol & 928 & 3.66 & 1.11 & 3805 & 3.70 & 1.03 & 360 & 3.80 & 1.10 & 0.87 & 0.39 & 1.96 & 0.05 \\
\hline Triglycerides & 931 & 1.69 & 1.23 & 3822 & 1.56 & 0.98 & 361 & 1.66 & 1.07 & -2.92 & 0.004 & -0.37 & 0.71 \\
\hline 25-hydroxyvitamin D3 & 880 & 44.92 & 16.55 & 3672 & 45.57 & 16.85 & 342 & 43.58 & 16.97 & 1.03 & 0.30 & -1.25 & 0.21 \\
\hline Insulin & 905 & 9.11 & 9.06 & 3762 & 9.71 & 14.37 & 348 & 9.41 & 7.63 & -1.59 & 0.11 & -0.61 & 0.54 \\
\hline Weight & 930 & 77.00 & 16.20 & 3819 & 76.15 & 15.33 & 360 & 75.97 & 15.22 & -1.44 & 0.15 & -1.07 & 0.29 \\
\hline Waist circumference & 922 & 93.90 & 14.11 & 3792 & 92.03 & 13.06 & 354 & 93.21 & 13.51 & -3.67 & 0.0003 & -0.81 & 0.42 \\
\hline BMI & 930 & 27.45 & 5.01 & 3818 & 26.77 & 4.61 & 360 & 26.63 & 4.49 & -3.74 & 0.0002 & -2.85 & 0.004 \\
\hline GSS & 874 & 8.00 & 2.87 & 3734 & 5.07 & 2.47 & 361 & 0.00 & 0.00 & -27.82 & $<2.2 \mathrm{e}-16$ & -82.42 & $<2.2 \mathrm{e}-16$ \\
\hline Systolic blood pressure & 925 & 133.51 & 21.52 & 3816 & 134.11 & 21.02 & 361 & 136.06 & 20.36 & 0.76 & 0.45 & 1.98 & 0.05 \\
\hline $\begin{array}{l}\text { Diastolic blood } \\
\text { pressure }\end{array}$ & 923 & 81.33 & 11.48 & 3814 & 81.70 & 11.24 & 361 & 81.81 & 10.63 & 0.88 & 0.38 & 0.71 & 0.48 \\
\hline HOMA-IR & 905 & 2.68 & 4.32 & 3760 & 2.46 & 6.31 & 348 & 2.58 & 3.17 & -1.26 & 0.21 & -0.44 & 0.66 \\
\hline HOMA-B & 903 & 95.47 & 69.71 & 3755 & 94.37 & 159.25 & 347 & 87.12 & 53.28 & -0.32 & 0.75 & -2.27 & 0.02 \\
\hline GHQ & 908 & 3.89 & 3.95 & 3787 & 1.49 & 2.48 & 355 & 0.86 & 2.04 & -17.50 & $<2.2 \mathrm{e}-16$ & -17.82 & $<2.2 \mathrm{e}-16$ \\
\hline MBI & 485 & 1.82 & 1.11 & 2421 & 1.06 & 0.81 & 175 & 0.80 & 0.78 & -14.33 & $<2.2 \mathrm{e}-16$ & -13.10 & $<2.2 \mathrm{e}-16$ \\
\hline Hours of sleep & 891 & 7.47 & 1.36 & 3685 & 7.46 & 1.05 & 343 & 7.50 & 1.33 & -0.21 & 0.84 & 0.34 & 0.73 \\
\hline Hip circumference & 921 & 102.86 & 10.29 & 3792 & 101.40 & 9.30 & 354 & 100.89 & 9.46 & -3.93 & 0.0001 & -3.25 & 0.001 \\
\hline
\end{tabular}

HDL, high-density lipoprotein.

LDL, low-density lipoprotein.

BMI, body-mass index.

GSS, global seasonality score.

HOMA-IR, insulin resistance index.

HOMA-B, beta-cell function index.

the genotyping multiplexes. These additional SNPs were selected using Pupasuite (Conde et al., 2006), Variowatch (Cheng et al., 2012) and dbSMR (Hariharan et al., 2009) databases. See Table 1 for the altogether 42 selected SNPs.

\subsection{Genotyping}

Genomic DNA was isolated from whole blood according to standard procedures. The SNPs were genotyped at the Institute for Molecular Medicine Finland, Technology Centre, University of Helsinki using the MassARRAY iPLEX method (Sequenom, San Diego, CA, USA) (Jurinke et al., 2002), with excellent success ( $>95 \%$ ) and accuracy (100\%) rates (Lahermo et al., 2006). For quality control purposes, positive (CEPH) and negative water controls were included in each 384-plate. Genotyping was performed blind to phenotypic information.

171 of 5910 individuals were excluded due to a high missing genotype rate (i.e. $>0.1$ ). The total genotyping rate in the remaining individuals was 0.999. Three CRY2 SNPs turned out to be non-polymorphic (rs35488012, rs117531403, rs76545099). Two SNPs were excluded from the analyses because their minor allele frequency was less than 0.01 (CRY2 rs3747548, CRY1 rs7294758). Finally, there were 5739 individuals and 37 SNPs for the statistical analyses.

\subsection{Statistical analyses}

Statistical analyses were performed using logistic regression and additive genetic model controlling for age and sex with PLINK software v1.07 (Purcell et al., 2007). Subjects having problematic seasonal variations were compared to subjects with non-problematic seasonal variations, and to subjects with no seasonal variation. A change in the seasonal variations for the better, and a change for the worse were compared to no change. Haplotype blocks were defined using Haploview software (Barrett et al., 2005) and the confidence interval algorithm. Only haplotypes with more than 5\% frequency are reported. In order to corrected for the multiple SNPs within a gene, the gene-based analysis was conducted using the set-based test in PLINK software with the default settings and 10,000 permutations, yielding the empirical p-values.

\section{Results}

In Table 1, the genotypes, allele frequencies and the HardyWeinberg equilibrium p-values are shown for all the 42 SNPs that were successfully genotyped in this study. The general characteristics of all the participants are presented in Table 2 and for the three groups in Table 3. The group with problematic variation had the highest BMI and hip circumference. The group with non-problematic variation had lowest triglycerides and waist circumference. The group with no variation had highest LDL cholesterol and systolic blood pressure and lowest HOMA-IR. The Haploview analysis yielded three haplotype blocks for CRY1 and one haplotype block for CRY2 gene (Figs. 2 and 3) which had 11 and five common ( $>5 \%$ frequency) haplotypes, respectively.

\subsection{Cross-sectional analysis}

CRY1 SNP rs714359 ( $A$ allele, $O R=1.33,95 \%$ CI 1.07-1.66, $p=0.01$; see Table 4 ) showed nominally significant association with the problematicity of seasonal variations (problematic vs. no variation), and rs714359 ( $A$ allele, $O R=1.14,95 \% C I$ 1.01-1.29, $p=0.03$ ) and rs2287161 ( $C$ allele, $O R=0.90,95 \%$ CI $0.81-1.00$, $p=0.05$ ) with the problematicity of seasonal variations (problematic vs. non-problematic). The set-based analysis did not support 


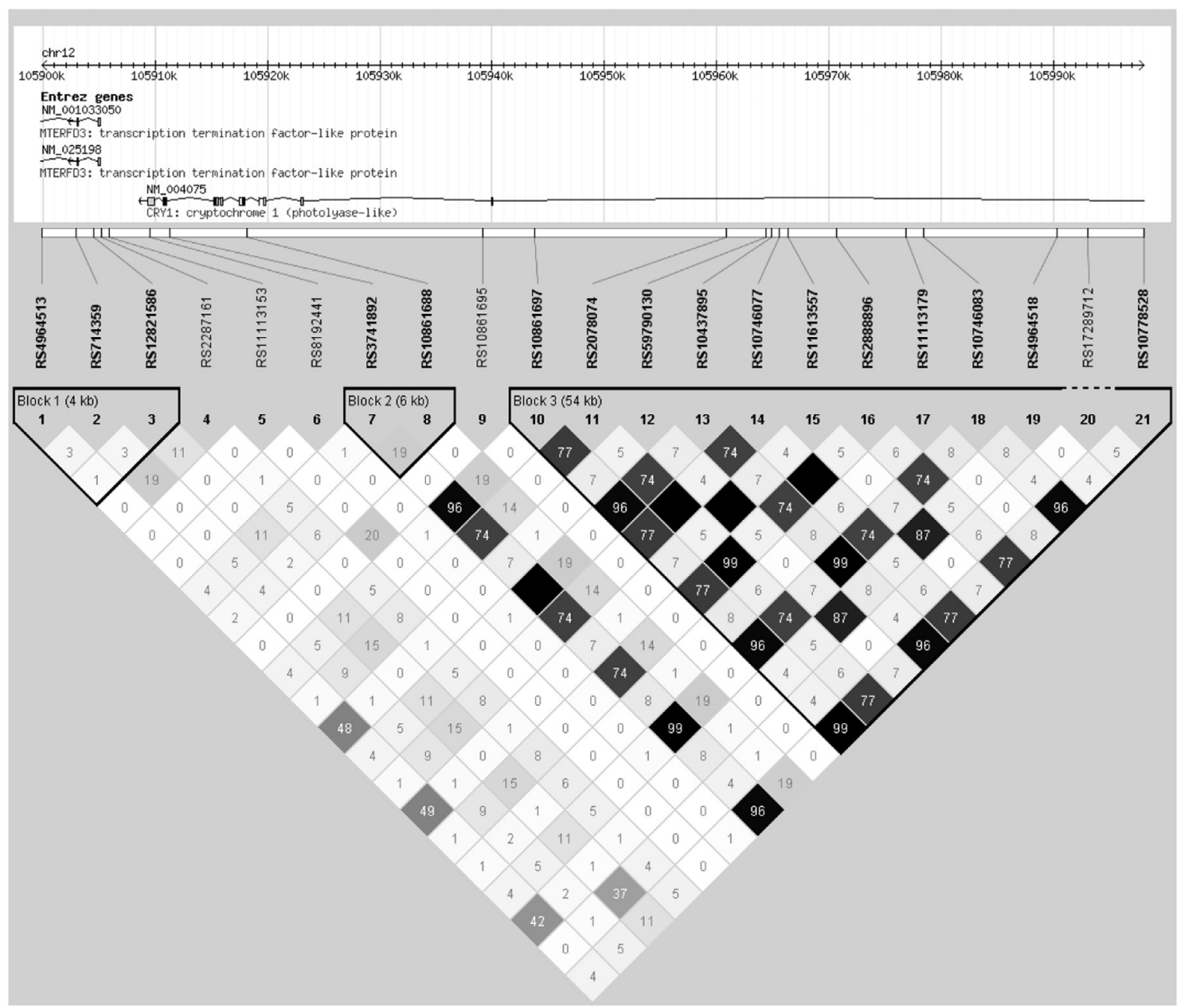

Fig. 2. The analyzed CRY1 SNPs, their location and the haplotype block structure constructed using the Haploview program showing $\mathrm{r}^{2}$ values.

these associations (Table 5). However, the CRY1 haplotype TAG including rs714359 showed nominally significant association with the problematicity of seasonal variations (problematic vs. no variation, $O R=1.33, p=0.01$; and problematic vs. non-problematic, $O R=1.14, p=0.03$; see Table 6). All the SNP and haplotype association analysis results are shown in Supplementary material 2 (Supplementary Table 3 for SNP association results and Supplementary Table 4 for haplotype association results).

CRY2 SNPs rs1554338 ( $G$ allele, $O R=0.67,95 \%$ CI 0.51-0.87, $p=0.0035$ ) and rs72902437 ( $C$ allele, $O R=1.45,95 \%$ CI 1.08-1.93, $p=0.01$; see Table 4 ) showed nominally significant association with the problematicity of seasonal variations (problematic variation vs. non-problematic variation). The set-based analysis supported the association of the two SNPs with the problematicity (empirical set-based $p=0.03$; see Table 5). The CRY2 haplotype TTTCACAATGGCACT (OR=0.77, $p=0.03$; see Table 6$)$ was also associated with the problematicity of seasonal variations (problematic variation vs. non-problematic variation).

\subsection{Longitudinal analysis}

CRY2 SNP rs61884508 ( $G$ allele, $O R=0.52,95 \%$ CI 0.33-0.82, $p=0.004, q=0.14$; see Table 3 ) was associated with worsening of the problematicity of seasonal variations during the follow-up. The set-based analysis supported the SNP association (empirical setbased $p=0.02$; see Table 5).

\subsection{Additional analysis}

For the aforementioned five SNPs, the results from their associations with the laboratory measurements are given in Supplementary material 3 . Among those with problematic seasonal variations, the AA-genotypes of CRY1 SNP rs714359 had lower HDL cholesterol levels, higher insulin levels, and greater HOMA-IR and HOMA-B indices than GG-genotypes, the GA genotypes being intermediate. Concerning the CRY1 SNP rs2287161, among those with no seasonal variation the CG-genotypes had lower HDL cholesterol levels than CC-genotypes, and among those with nonproblematic seasonal variations the GG-genotypes had lower HDL cholesterol levels than CG-genotypes.

The TT-genotypes, as compared with the CT-genotypes, of CRY2 SNP rs72902437 had greater HOMA-B indices among those with non-problematic seasonal variations, and higher systolic and diastolic blood pressures among those with no seasonal variation. Concerning the CRY2 SNP rs1554338, the GG-genotypes had higher total and LDL cholesterol levels and lower HDL cholesterol levels than the AA-genotypes among those with non-problematic seasonal variations.

Among those with worsening of the problematicity of seasonal variations, the TT-genotype carriers, as compared with the GTgenotype carriers, of CRY2 SNP rs61884508 had higher levels of triglycerides at the baseline. 


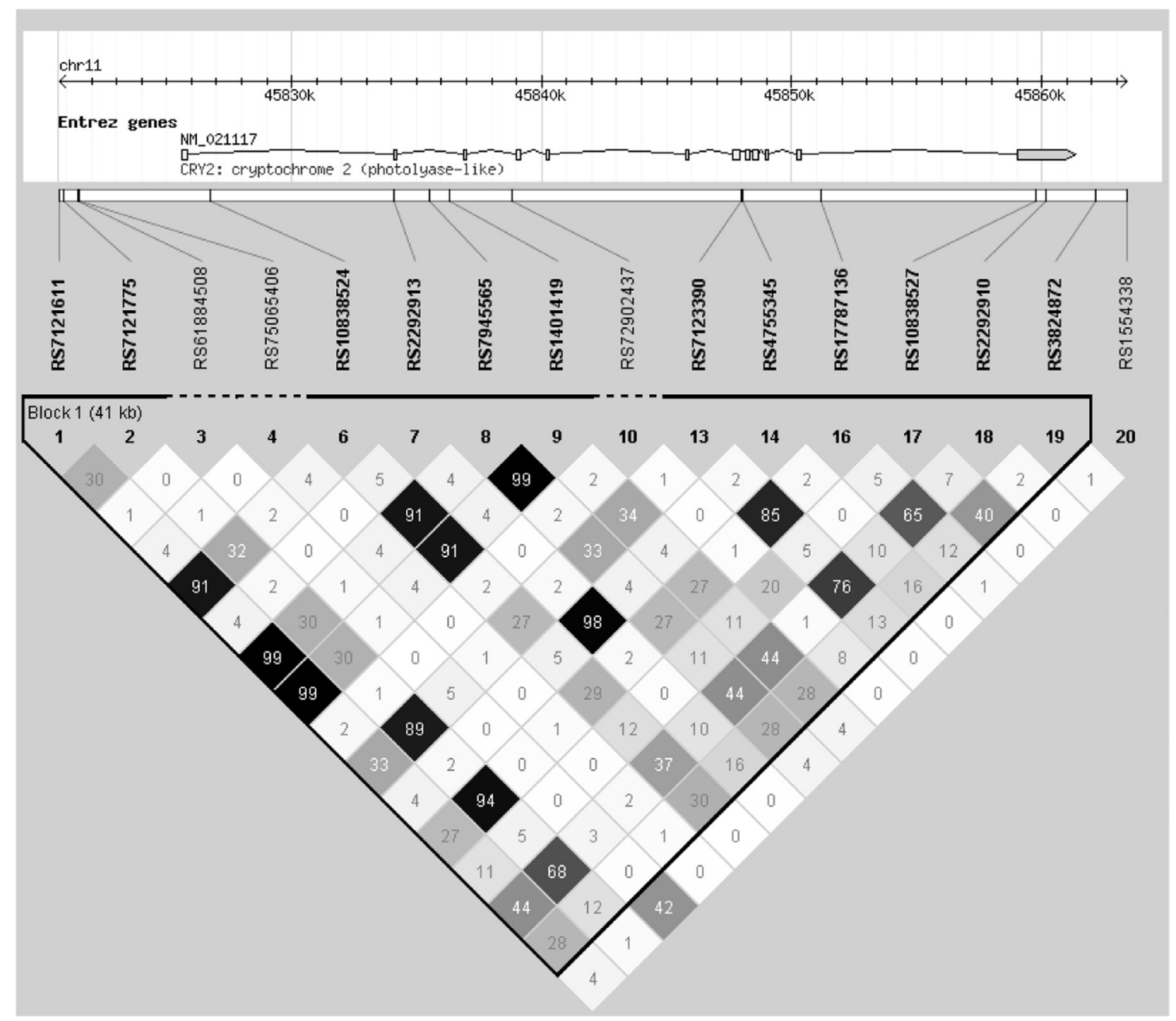

Fig. 3. The analyzed CRY2 SNPs, their location and the haplotype block structure constructed using the Haploview program showing $\mathrm{r}^{2}$ values.

Table 4

Longitudinal and cross-sectional nominally significant $(\mathrm{p}<0.05) C R Y 1$ and $C R Y 2$ SNP association results.

\begin{tabular}{lllllllll}
\hline Gene & Phenotype & SNP & A1 & $n$ & OR & L95 & U95 & $p$ \\
\hline CRY1 & $\begin{array}{l}\text { Problematic vs. no } \\
\text { variation }\end{array}$ & $\operatorname{rs714359}$ & $A$ & 1289 & 1.33 & 1.07 & 1.66 & 0.01 \\
& $\begin{array}{l}\text { Problematic vs. } \\
\text { non-problematic }\end{array}$ & rs714359 & $A$ & 4746 & 1.14 & 1.01 & 1.29 & 0.03 \\
$\begin{array}{l}\text { Problematic vs. } \\
\text { non-problematic }\end{array}$ & rs2287161 & $C$ & 4732 & 0.90 & 0.81 & 1.00 & 0.05 \\
CRY2 & $\begin{array}{l}\text { Problematic vs. } \\
\text { non-problematic }\end{array}$ & $\operatorname{rs} 1554338$ & $G$ & 4752 & 0.67 & 0.51 & 0.87 & 0.003 \\
& $\begin{array}{l}\text { Problematic vs. } \\
\text { non-problematic } \\
\text { Worse }\end{array}$ & $\operatorname{rs} 72902437$ & $C$ & 4746 & 1.45 & 1.08 & 1.93 & 0.01 \\
\hline
\end{tabular}

Abbreviations: A1; Tested allele (minor allele). N; Number of genotypes for the phenotype. OR; Odds ratio. L95, U95; Lower and upper bounds of $95 \%$ confidence interval for odds ratio.

\section{Discussion}

In the longitudinal analysis, we found evidence that carriers of the CRY2 SNP rs61884508 G-allele had the decreased odds for the worsening of the seasonal variations in mood and behavior as a problem during the 11-year follow-up. In addition, in among the participants that had worsening of the seasonal variations, the
Table 5

Results of the set-based analysis.

\begin{tabular}{|c|c|c|c|c|c|c|}
\hline SET & Phenotype & NSNP & NSIG & NSIGLD & EMP & SNPs \\
\hline \multirow[t]{4}{*}{ CRY1 } & $\begin{array}{l}\text { Problematic vs. no } \\
\text { variation }\end{array}$ & 21 & 1 & 1 & 0.07 & rs714359 \\
\hline & $\begin{array}{l}\text { Problematic vs. non- } \\
\text { problematic }\end{array}$ & 21 & 2 & 2 & 0.31 & $\begin{array}{l}\text { rs714359l } \\
\text { rs2287161 }\end{array}$ \\
\hline & Better & 21 & 0 & 0 & 1.00 & - \\
\hline & Worse & 21 & 0 & 0 & 1.00 & - \\
\hline \multirow[t]{4}{*}{ CRY2 } & $\begin{array}{l}\text { Problematic vs. no } \\
\text { variation }\end{array}$ & 16 & 0 & 0 & 1.00 & - \\
\hline & $\begin{array}{l}\text { Problematic vs. non- } \\
\text { problematic }\end{array}$ & 16 & 2 & 2 & 0.03 & $\begin{array}{l}\text { rs1554338I } \\
\text { rs72902437 }\end{array}$ \\
\hline & Better & 16 & 0 & 0 & 1.00 & - \\
\hline & Worse & 16 & 1 & 1 & 0.02 & rs61884508 \\
\hline
\end{tabular}

Abbreviations: NSNP; Number of SNPs in the set. NSIG; Number of SNPs with $\mathrm{p}<0.05$. NSIGLD; Number of significant SNPs also passing LD-criterion $\left(r^{2}>0.5\right)$. EMP; Empirical set-based $p$-value. SNPs; List of SNPs in the set.

triglycerides levels were associated with the CRY2 SNP rs61884508, the carriers of GT-genotype having lower levels of triglycerides than the carriers of TT-genotype. The CRY2 SNP rs61884508 is located upstream of CRY2 gene and was selected to be genotyped because it is located within a putative transcription factor binding site, and it could thus have a role in transcriptional regulation.

In the cross-sectional analysis, we found that the SNP 
Table 6

Longitudinal and cross-sectional nominally significant $C R Y 1$ and $C R Y 2$ haplotype association results.

\begin{tabular}{|c|c|c|c|c|c|c|c|}
\hline Gene & Phenotype & SNP1 & SNP2 & Haplotype & $F$ & OR & $p$ \\
\hline \multirow[t]{2}{*}{ CRY1 } & Problematic vs. no variation & rs4964513 & rs12821586 & TAG & 0.22 & 1.33 & 0.01 \\
\hline & Problematic vs. non-problematic & rs4964513 & rs12821586 & TAG & 0.22 & 1.14 & 0.03 \\
\hline CRY2 & Problematic vs. non-problematic & rs7121611 & rs3824872 & TTTCACAATGGCACT & 0.06 & 0.77 & 0.03 \\
\hline
\end{tabular}

Abbreviations: SNP1; SNP ID of the first SNP (5'). SNP2; SNP ID of the last SNP (3'). OR; Odds ratio. F; frequency of the haplotype.

rs1554338 G-allele protected and CRY2 SNP rs72902437 C-allele predisposed to more severe seasonal variations, i.e., those being problematic vs. non-problematic to the individual. Earlier, the SNP rs1554338 G-allele has been associated with having the seasonal pattern in bipolar disorder (Geoffroy et al., 2015) and nominally $(\mathrm{p}=0.031$, not holding after multiple correction) with bipolar I disorder. Here, we found that the GG-genotype associated with both higher total and higher LDL cholesterol levels but lower HDL cholesterol levels compared to AA-genotype, indicating an unfavorable circulating lipids profile, and that it was seen only among those with non-problematic seasonal variations. Intriguingly, the SNP rs1554338 is located in the upstream of MAPK8IP1 (downstream of CRY2). The MAPK8IP1 gene is indicated in the pancreatic beta-cell function (Waeber et al., 2000), and its scaffolding protein MAPK8IP1 (mitogen-activated protein kinase 8 interacting protein 1 ) is a key regulator of autophagosome transport in neurons (Fu and Holzbaur, 2014) and has a role in protection of dopaminergic neurons and levels of catecholamines in the striatum (Xia et al., 2001).

We also found that if there were seasonal variations in mood and behavior but they were not a problem, the CRY2 SNP rs72902437 CT-genotype was associated with a lower HOMA-B index, or a worse beta-cell function compared to TT-genotype, indicating an increased diabetes risk. In contrast, among those with no seasonal variation, systolic and diastolic blood pressures were lower in the carriers of the CRY2 SNP rs72902437 CT-genotype compared to TT-genotype, indicating a decreased hypertension risk.

The $A$-allele of $C R Y 2$ SNP rs10838524 that was earlier associated with greater chronicity of depressive symptoms in patients with major depressive or bipolar disorder (Fiedorowicz et al., 2012) did not associate with seasonality in our study. However, the A-allele of the CRY2 SNP rs10838524 was part of TTTCACAATGGCACT haplotype that protected from seasonal variations being problematic in our cross-sectional analysis.

The CRY1 SNP rs714359 was indicated to influence not only HDL cholesterol levels, but also insulin levels and beyond, as it was involved in insulin resistance and beta-cell function as well. Intriguingly, this influence was seen only among those with problematic seasonal variations. These findings are well in agreement with the earlier report of the influence of the CRY1 SNP rs2287161 had on fasting insulin and insulin resistance (Dashti et al., 2014).

Our study has some strengths and limitations. Our dataset was rather big and derived from a nationwide representative sample of the general adult population aged 30 years and over. In addition, the cryptochrome genes were well covered. We report here, for the first time, longitudinal data on the influence of CRY2 genetic variants on the seasonal variations in mood and behavior experienced as a problem. Since problematic seasonal symptoms of mood and behavior are common on population level, our findings might help early identification of individuals who will have worsening of these symptoms.

On the other hand, weaknesses of our study are that the assessment of seasonal variations in mood and behavior was based on the self-report only, and that some participants were lost in the follow-up. In addition, the associated SNPs and haplotype were rather rare. Therefore, replication in another independent sample is needed to confirm our findings, since the minor allele frequency is known to affect the likelihood of a false positive result.

In conclusion, this association analysis has demonstrated an effect of $C R Y 2$ genetic variants in the problematic seasonal variations, and more importantly, with worsening of these seasonal variations as a problem in a longitudinal analysis.

\section{Appendix A. Supplementary material}

Supplementary data associated with this article can be found in the online version at http://dx.doi.org/10.1016/j.psychres.2016.05. 044 .

\section{References}

Anand, S.N., Maywood, E.S., Chesham, J.E., Joynson, G., Banks, G.T., Hastings, M.H. Nolan, P.M., 2013. Distinct and separable roles for endogenous CRY1 and CRY2 within the circadian molecular clockwork of the suprachiasmatic nucleus, as revealed by the Fbxl3Afh mutation. J. Neurosci. 33, 7145-7153.

Aromaa, A., Koskinen, S., 2004. Health and functional capacity in Finland. Baseline Results of the Health 2000 Health Examination Survey, National Public Health Institute B:12/2004, 2004

Barker, A., Sharp, S.J., Timpson, N.J., Bouatia-Naji, N., Warrington, N.M., Kanoni, S, Beilin, L.J., Brage, S., Deloukas, P., Evans, D.M., Grontved, A., Hassanali, N. Lawlor, D.A., Lecoeur, C., Loos, R.J., Lye, S.J., McCarthy, M.I., Mori, T.A., Ndiaye, N. C., Newnham, J.P., Ntalla, I., Pennell St, C.E., Pourcain, B., Prokopenko, I., Ring, S M., Sattar, N., Visvikis-Siest, S., Dedoussis, G.V., Palmer, L.J., Froguel, P., Smith, G. D., Ekelund, U., Wareham, N.J., Langenberg, C., 2011. Association of genetic Loci with glucose levels in childhood and adolescence: a meta-analysis of over 6000 children. Diabetes 60, 1805-1812.

Barrett, J.C., Fry, B., Maller, J., Daly, M.J., 2005. Haploview: analysis and visualization of LD and haplotype maps. Bioinformatics 21, 263-265.

Boothroyd, C.E., Wijnen, H., Naef, F., Saez, L., Young, M.W., 2007. Integration of light and temperature in the regulation of circadian gene expression in Drosophila. PLoS Genet. 3, e54.

Buhr, E.D., Yoo, S.H., Takahashi, J.S., 2010. Temperature as a universal resetting cue for mammalian circadian oscillators. Science 330, 379-385.

Bunney, J.N., Potkin, S.G., 2008. Circadian abnormalities, molecular clock genes and chronobiological treatments in depression. Br. Med. Bull. 86, 23-32.

Cheng, Y.C., Hsiao, F.C., Yeh, E.C., Lin, W.J., Tang, C.Y., Tseng, H.C., Wu, H.T., Liu, C.K. Chen, C.C., Chen, Y.T., Yao, A., 2012. VarioWatch: providing large-scale and comprehensive annotations on human genomic variants in the next generation sequencing era. Nucleic Acids Res, 40, W76-W81.

Conde, L., Vaquerizas, J.M., Dopazo, H., Arbiza, L., Reumers, J., Rousseau, F. Schymkowitz, J., Dopazo, J., 2006. PupaSuite: finding functional single nucleotide polymorphisms for large-scale genotyping purposes. Nucleic Acids Res. 34 W621-W625.

Dardente, H., Fortier, E.E., Martineau, V., Cermakian, N., 2007. Cryptochromes impair phosphorylation of transcriptional activators in the clock: a general mechanism for circadian repression. Biochem. J 402, 525-536.

Dashti, H.S., Smith, C.E., Lee, Y.C., Parnell, L.D., Lai, C.Q., Arnett, D.K., Ordovas, J.M., Garaulet, M., 2014. CRY1 circadian gene variant interacts with carbohydrate intake for insulin resistance in two independent populations: Mediterranean and North American. Chronobiol. Int. 31, 660-667.

Dupuis, J., Langenberg, C., Prokopenko, I., Saxena, R., Soranzo, N., Jackson, A.U., Wheeler, E., Glazer, N.L., Bouatia-Naji, N., Gloyn, A.L., Lindgren, C.M., Magi, R., Morris, A.P., Randall, J., Johnson, T., Elliott, P., Rybin, D., Thorleifsson, G., Steinthorsdottir, V., Henneman, P., Grallert, H., Dehghan, A., Hottenga, J.J., Franklin, C. S., Navarro, P., Song, K., Goel, A., Perry, J.R., Egan, J.M., Lajunen, T., Grarup, N., Sparso, T., Doney, A., Voight, B.F., Stringham, H.M., Li, M., Kanoni, S., Shrader, P., Cavalcanti-Proenca, C., Kumari, M., Qi, L., Timpson, N.J., Gieger, C., Zabena, C., Rocheleau, G., Ingelsson, E., An, P., O’Connell, J., Luan, J., Elliott, A., McCarroll, S A., Payne, F., Roccasecca, R.M., Pattou, F., Sethupathy, P., Ardlie, K., Ariyurek, Y. Balkau, B., Barter, P., Beilby, J.P., Ben-Shlomo, Y., Benediktsson, R., Bennett, A.J., 
Bergmann, S., Bochud, M., Boerwinkle, E., Bonnefond, A., Bonnycastle, L.L., Borch-Johnsen, K., Bottcher, Y., Brunner, E., Bumpstead, S.J., Charpentier, G., Chen, Y.D., Chines, P., Clarke, R., Coin, L.J., Cooper, M.N., Cornelis, M., Crawford, G., Crisponi, L., Day, I.N., de Geus, E.J., Delplanque, J., Dina, C., Erdos, M.R., Fedson, A.C., Fischer-Rosinsky, A., Roccasecca, N.G., Fox, C.S., Frants, R., Franzosi, M.G., Galan, P., Goodarzi, M.O., Graessler, I., Groves, C.J., Grundy, S., Gwilliam, R., Gyllensten, U., Hadjadj, S., Hallmans, G., Hammond, N., Han, X., Hartikainen, A. L., Hassanali, N., Hayward, C., Heath, S.C., Hercberg, S., Herder, C., Hicks, A.A., Hillman, D.R., Hingorani, A.D., Hofman, A., Hui, J., Hung, J., Isomaa, B., Johnson, P.R., Jorgensen, T., Jula, A., Kaakinen, M., Kaprio, J., Kesaniemi, Y.A., Kivimaki, M. Knight, B., Koskinen, S., Kovacs, P., Kyvik, K.O., Lathrop, G.M., Lawlor, G., Le Bacquer, O., Lecoeur, C., Li, Y., Lyssenko, V., Mahley, R., Mangino, M., Manning, A. K., Martinez-Larrad, M.T., McAteer, J.B., McCulloch, L.J., McPherson, R., Meisinger, C., Melzer, D., Meyre, D., Mitchell, B.D., Morken, M.A., Mukherjee, S., Naitza, S., Narisu, N., Neville, M.J., Oostra, B.A., Orru, M., Pakyz, R., Palmer, C.N., Paolisso, G., Pattaro, C., Pearson, D., Peden, J.F., Pedersen, N.L., Perola, M., Pfeiffer, A.F., Pichler, I., Polasek, O., Posthuma, D., Potter, S.C., Pouta, A., Province M.A., Psaty, B.M., Rathmann, W., Rayner, N.W., Rice, K., Ripatti, S., Rivadeneira, F., Roden, M., Rolandsson, O., Sandbaek, A., Sandhu, M., Sanna, S., Sayer, A.A., Scheet, P., Scott, L.J., Seedorf, U., Sharp, S.J., Shields, B., Sigurethsson, G., Sijbrands, E.J., Silveira, A., Simpson, L., Singleton, A., Smith, N.L., Sovio, U., Swift, A., Syddall, H., Syvanen, A.C., Tanaka, T., Thorand, B., Tichet, J., Tonjes, A., Tuomi, T., Uitterlinden, A.G., van Dijk, K.W., van Hoek, M., Varma, D., Visvikis-Siest, S. Vitart, V., Vogelzangs, N., Waeber, G., Wagner, P.J., Walley, A., Walters, G.B., Ward, K.L., Watkins, H., Weedon, M.N., Wild, S.H., Willemsen, G., Witteman, J.C. Yarnell, J.W., Zeggini, E., Zelenika, D., Zethelius, B., Zhai, G., Zhao, J.H., Zillikens, M.C., DIAGRAM, Consortium, GIANT, Consortium, Global BPgen Consortium, Borecki, I.B., Loos, R.J., Meneton, P., Magnusson, P.K., Nathan, D.M., Williams, G. H., Hattersley, A.T., Silander, K., Salomaa, V., Smith, G.D., Bornstein, S.R., Schwarz, P., Spranger, J., Karpe, F., Shuldiner, A.R., Cooper, C., Dedoussis, G.V., Serrano-Rios, M., Morris, A.D., Lind, L., Palmer, L.J., Hu, F.B., Franks, P.W., Ebrahim, S., Marmot, M., Kao, W.H., Pankow, J.S., Sampson, M.J., Kuusisto, J., Laakso, M., Hansen, T., Pedersen, O., Pramstaller, P.P., Wichmann, H.E., Illig, T., Rudan, I., Wright, A.F., Stumvoll, M., Campbell, H., Wilson, J.F., Anders Hamsten on behalf of Procardis Consortium, M.A.G.I.C. investigators, Bergman, R.N., Buchanan, T.A., Collins, F.S., Mohlke, K.L., Tuomilehto, J., Valle, T.T., Altshuler, D., Rotter, J.I., Siscovick, D.S., Penninx, B.W., Boomsma, D.I., Deloukas, P., Spector, T.D., Frayling, T.M., Ferrucci, L., Kong, A., Thorsteinsdottir, U., Stefansson, K., van Duijn, C. M., Aulchenko, Y.S., Cao, A., Scuteri, A., Schlessinger, D., Uda, M., Ruokonen, C., Jarvelin, M.R., Waterworth, D.M., Vollenweider, P., Peltonen, D., Mooser, V., Abecasis, G.R., Wareham, N.J., Sladek, R., Froguel, P., Watanabe, R.M., Meigs, J.B., Groop, L., Boehnke, M., McCarthy, M.I., Florez, J.C., Barroso, I., 2010. New genetic loci implicated in fasting glucose homeostasis and their impact on type 2 diabetes risk. Nat. Genet. 42, 105-116.

Evans, J.A., Suen, T.C., Callif, B.L., Mitchell, A.S., Castanon-Cervantes, O., Baker, K.M., Kloehn, I., Baba, K., Teubner, B.J., Ehlen, J.C., Paul, K.N., Bartness, T.J., Tosini, G. Leise, T., Davidson, A.J., 2015. Shell neurons of the master circadian clock coordinate the phase of tissue clocks throughout the brain and body. BMC Biol. 13 43-015-0157-x.

Fiedorowicz, J.G., Coryell, W.H., Akhter, A., Ellingrod, V.L., 2012. Chryptochrome 2 variants, chronicity, and seasonality of mood disorders. Psychiatr. Genet. 22, 305-306.

Francois, P., Despierre, N., Siggia, E.D., 2012. Adaptive temperature compensation in circadian oscillations. PLoS Comput. Biol. 8, e1002585.

Friedewald, W.T., Levy, R.I., Fredrickson, D.S., 1972. Estimation of the concentration of low-density lipoprotein cholesterol in plasma, without use of the preparative ultracentrifuge. Clin. Chem. 18, 499-502.

Fu, M.M., Holzbaur, E.L., 2014. MAPK8IP1/JIP1 regulates the trafficking of autophagosomes in neurons. Autophagy 10, 2079-2081.

Geoffroy, P.A., Lajnef, M., Bellivier, F., Jamain, S., Gard, S., Kahn, J.P., Henry, C., Leboyer, M., Etain, B., 2015. Genetic association study of circadian genes with seasonal pattern in bipolar disorders. Sci. Rep. 5, 10232.

Grimaldi, S., Partonen, T., Haukka, J., Aromaa, A., Lonnqvist, J., 2009. Seasonal vegetative and affective symptoms in the Finnish general population: testing the dual vulnerability and latitude effect hypotheses. Nord. J. Psychiatry 63 397-404.

Hariharan, M., Scaria, V., Brahmachari, S.K., 2009. dbSMR: a novel resource of genome-wide SNPs affecting microRNA mediated regulation. BMC Bioinform. 10, 108.

Hua, P., Liu, W., Chen, D., Zhao, Y., Chen, L., Zhang, N., Wang, C., Guo, S., Wang, L., Xiao, H., Kuo, S.H., 2014. Cry1 and Tef gene polymorphisms are associated with major depressive disorder in the Chinese population. J. Affect. Disord. 157, $100-103$.

Jurinke, C., van den Boom, D., Cantor, C.R., Koster, H., 2002. Automated genotyping using the DNA MassArray technology. Methods Mol. Biol. 187, 179-192.

Kasper, S., Wehr, T.A., Bartko, J.J., Gaist, P.A., Rosenthal, N.E., 1989. Epidemiological findings of seasonal changes in mood and behavior. A telephone survey of Montgomery County, Maryland. Arch. Gen. Psychiatry 46, 823-833.

Kaushik, R., Nawathean, P., Busza, A., Murad, A., Emery, P., Rosbash, M., 2007. PERTIM interactions with the photoreceptor cryptochrome mediate circadian temperature responses in Drosophila. PLoS Biol. 5, e146.

Kelly, M.A., Rees, S.D., Hydrie, M.Z., Shera, A.S., Bellary, S., O'Hare, J.P., Kumar, S., Taheri, S., Basit, A., Barnett, A.H., DIAGRAM Consortium, S.A.T.2D. Consortium, 2012. Circadian gene variants and susceptibility to type 2 diabetes: a pilot study. PLoS One 7, e32670.

Kovanen, L., Kaunisto, M., Donner, K., Saarikoski, S.T., Partonen, T., 2013. CRY2 genetic variants associate with dysthymia. PLoS One 8, e71450.

Lahermo, P., Liljedahl, U., Alnaes, G., Axelsson, T., Brookes, A.J., Ellonen, P., Groop, P. H., Hallden, C., Holmberg, D., Holmberg, K., Keinanen, M., Kepp, K., Kere, J., Kiviluoma, P., Kristensen, V., Lindgren, C., Odeberg, J., Osterman, P., Parkkonen, M., Saarela, J., Sterner, M., Stromqvist, L., Talas, U., Wessman, M., Palotie, A., Syvanen, A.C., 2006. A quality assessment survey of SNP genotyping laboratories. Hum. Mutat. 27, 711-714.

Lamia, K.A., Papp, S.J., Yu, R.T., Barish, G.D., Uhlenhaut, N.H., Jonker, J.W., Downes, M., Evans, R.M., 2011. Cryptochromes mediate rhythmic repression of the glucocorticoid receptor. Nature 480, 552-556.

Lavebratt, C., Sjoholm, L.K., Soronen, P., Paunio, T., Vawter, M.P., Bunney, W.E., Adolfsson, R., Forsell, Y., Wu, J.C., Kelsoe, J.R., Partonen, T., Schalling, M., 2010. CRY2 is associated with depression. PLoS One 5, e9407.

Lincoln, G., Messager, S., Andersson, H., Hazlerigg, D., 2002. Temporal expression of seven clock genes in the suprachiasmatic nucleus and the pars tuberalis of the sheep: evidence for an internal coincidence timer. Proc. Natl. Acad. Sci. USA 99, 13890-13895.

Machicao, F., Peter, A., Machann, J., Konigsrainer, I., Bohm, A., Lutz, S.Z., Heni, M., Fritsche, A., Schick, F., Konigsrainer, A., Stefan, N., Haring, H.U., Staiger, H., 2016. Glucose-raising polymorphisms in the human clock gene cryptochrome 2 (CRY2) affect hepatic lipid content. PLoS One 11, e0145563.

Matthews, D.R., Hosker, J.P., Rudenski, A.S., Naylor, B.A., Treacher, D.F., Turner, R.C., 1985. Homeostasis model assessment: insulin resistance and beta-cell function from fasting plasma glucose and insulin concentrations in man. Diabetologia 28, 412-419.

McCarthy, M.J., Nievergelt, C.M., Shekhtman, T., Kripke, D.F., Welsh, D.K., Kelsoe, J.R., 2011. Functional genetic variation in the Rev-Erbalpha pathway and lithium response in the treatment of bipolar disorder. Genes Brain Behav. 10, 852-861.

Meijer, J.H., Michel, S., Vansteensel, M.J., 2007. Processing of daily and seasonal light information in the mammalian circadian clock. Gen. Comp. Endocrinol. 152, 159-164.

Nievergelt, C.M., Kripke, D.F., Remick, R.A., Sadovnick, A.D., McElroy, S.L., Keck Jr, P. E., Kelsoe, J.R., 2005. Examination of the clock gene cryptochrome 1 in bipolar disorder: mutational analysis and absence of evidence for linkage or association. Psychiatr. Genet. 15, 45-52.

Ono, D., Honma, S., Honma, K., 2013. Cryptochromes are critical for the development of coherent circadian rhythms in the mouse suprachiasmatic nucleus. Nat. Commun. 4, 1666.

Ozturk, N., Song, S.H., Ozgur, S., Selby, C.P., Morrison, L., Partch, C., Zhong, D., Sancar, A., 2007. Structure and function of animal cryptochromes. Cold Spring Harb. Symp. Quant. Biol. 72, 119-131.

Partonen, T., Lonnqvist, J., 1998. Seasonal affective disorder. Lancet 352, 1369-1374.

Patten, S.B., Williams, J.V., Lavorato, D.H., Bulloch, A.G., Fiest, K.M., Wang, J.L., Sajobi, T.T., 2016. Seasonal variation in major depressive episode prevalence in Canada. Epidemiol. Psychiatr. Sci., 1-8.

Purcell, S., Neale, B., Todd-Brown, K., Thomas, L., Ferreira, M.A., Bender, D., Maller, J., Sklar, P., de Bakker, P.I., Daly, M.J., Sham, P.C., 2007. PLINK: a tool set for wholegenome association and population-based linkage analyses. Am. J. Hum. Genet. 81, 559-575.

Renstrom, F., Koivula, R.W., Varga, T.V., Hallmans, G., Mulder, H., Florez, J.C., Hu, F.B., Franks, P.W., 2015. Season-dependent associations of circadian rhythm-regulating loci (CRY1, CRY2 and MTNR1B) and glucose homeostasis: the GLACIER Study. Diabetologia 58, 997-1005.

Rintamaki, R., Grimaldi, S., Englund, A., Haukka, J., Partonen, T., Reunanen, A., Aromaa, A., Lonnqvist, J., 2008. Seasonal changes in mood and behavior are linked to metabolic syndrome. PLoS One 3, e1482.

Rosenthal, N.E., Bradt, G.H., Wehr, T.A., 1984a. Seasonal Pattern Assessment Questionnaire. National Institute Of Mental Health., Bethesda, Maryland.

Rosenthal, N.E., Sack, D.A., Gillin, J.C., Lewy, A.J., Goodwin, F.K., Davenport, Y., Mueller, P.S., Newsome, D.A., Wehr, T.A., 1984b. Seasonal affective disorder. A description of the syndrome and preliminary findings with light therapy. Arch. Gen. Psychiatry 41, 72-80.

Shi, J., Wittke-Thompson, J.K., Badner, J.A., Hattori, E., Potash, J.B., Willour, V.L., McMahon, F.J., Gershon, E.S., Liu, C., 2008. Clock genes may influence bipolar disorder susceptibility and dysfunctional circadian rhythm. Am. J. Med. Genet. B. Neuropsychiatr. Genet. 147B, 1047-1055.

Sjoholm, L.K., Backlund, L., Cheteh, E.H., Ek, I.R., Frisen, L., Schalling, M., Osby, U., Lavebratt, C., Nikamo, P., 2010. CRY2 is associated with rapid cycling in bipolar disorder patients. PLoS One 5, e12632.

Soria, V., Martinez-Amoros, E., Escaramis, G., Valero, J., Perez-Egea, R., Garcia, C., Gutierrez-Zotes, A., Puigdemont, D., Bayes, M., Crespo, J.M., Martorell, L., Vilella, E., Labad, A., Vallejo, J., Perez, V., Menchon, J.M., Estivill, X., Gratacos, M., Urretavizcaya, M., 2010. Differential association of circadian genes with mood disorders: CRY1 and NPAS2 are associated with unipolar major depression and CLOCK and VIP with bipolar disorder. Neuropsychopharmacology 35, 1279-1289.

Stoleru, D., Nawathean, P., Fernandez, M.P., Menet, J.S., Ceriani, M.F., Rosbash, M., 2007. The Drosophila circadian network is a seasonal timer. Cell 129, 207-219.

Ukai-Tadenuma, M., Yamada, R.G., Xu, H., Ripperger, J.A., Liu, A.C., Ueda, H.R., 2011. Delay in feedback repression by cryptochrome 1 is required for circadian clock function. Cell 144, 268-281.

Waeber, G., Delplanque, J., Bonny, C., Mooser, V., Steinmann, M., Widmann, C., Maillard, A., Miklossy, J., Dina, C., Hani, E.H., Vionnet, N., Nicod, P., Boutin, P., Froguel, P., 2000. The gene MAPK8IP1, encoding islet-brain-1, is a candidate for type 2 diabetes. Nat. Genet. 24, 291-295.

Wehr, T.A., Rosenthal, N.E., 1989. Seasonality and affective illness. Am. J. Psychiatry 
$146,829-839$.

Wittchen, H.U., Lachner, G., Wunderlich, U., Pfister, H., 1998. Test-retest reliability of the computerized DSM-IV version of the Munich-composite international diagnostic interview (M-CIDI). Soc. Psychiatry Psychiatr. Epidemiol. 33, 568-578. Xia, X.G., Harding, T., Weller, M., Bieneman, A., Uney, J.B., Schulz, J.B., 2001. Gene transfer of the JNK interacting protein-1 protects dopaminergic neurons in the MPTP model of Parkinson's disease. Proc. Natl. Acad. Sci. USA 98, 10433-10438.
Ye, R., Selby, C.P., Chiou, Y.Y., Ozkan-Dagliyan, I., Gaddameedhi, S., Sancar, A., 2014 Dual modes of CLOCK:BMAL1 inhibition mediated by cryptochrome and period proteins in the mammalian circadian clock. Genes Dev. 28, 1989-1998.

Ye, R., Selby, C.P., Ozturk, N., Annayev, Y., Sancar, A., 2011. Biochemical analysis of the canonical model for the mammalian circadian clock. J. Biol. Chem. 286, 25891-25902. 